\title{
Uranium in Carbonaceous
}

Rocks in the Townsend and Helena Valleys

Montana

GEOLOGICAL SURVEY BULLETIN $1046-$ G

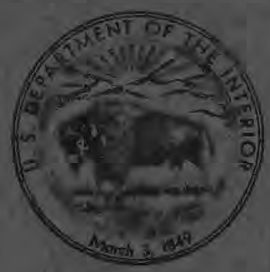


U. S. Geological Survey Bulletin 1046-G

Acknowledgment of cooperation with the U. S. Atomic Energy Commission was inadvertently omitted from the cover and title page of this bulletin. Will you please affix the enclosed gummed slips bearing acknowledgment to the left of the seal on these pages. 
. 


\section{Uranium in Carbonaceous}

Rocks in the Townsend

and Helena Valleys

Montana

By GEORGE E. BECRAFT

CONTRIBUTIONS TO THE GEOLOGY OF URANIUM

GE OL O G C A L S U R VEY B U L L E T I N 1046-G

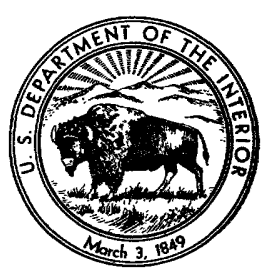

UNITED STATES GOVERNMENT PRINTING OFFICE, WASHINGTON : 1958 


\section{UNITED STATES DEPARTMENT OF THE INTERIOR}

FRED A. SEATON, Secretary

\section{GEOLOGICAL SURVEY}

Thomas B. Nolan, Director 


\section{CONTENTS}

Page

Abstract

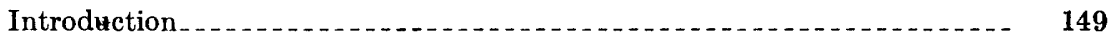

General geology . . . .

Geology and uranium deposits of areas examined in detail .

Area northeast of Winston

Geology ...

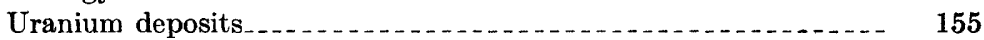

Locality A

Locality B $\ldots \ldots \ldots$

Locality C.................. 157

Locality D

Locality E...

Locality F

Locality G

Localities H-U...

Area west of Hauser Lake. $\ldots \ldots 160$

Area in T. 3 N., R. 1 W.

Area in T. 2 N.. R. 1 W.

Origin of the uranium deposits.

Suggestions for prospecting . .

Literature cited . . .

\section{ILLUSTRATIONS}

Page

Piate 3. Geologic map of the area northwest of Winston

In pocket

Figure 16. Index map of the Townsend and Helena Valleys........... 150

17. Geologic map of the area west of Hauser Lake .......... 160

18. Radioactivity anomalies in T. 3 N., R. 1 W., Townsend Valley

19. Radioactivity anomalies in T. 2 N., R. 1 W., Townsend

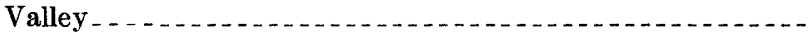





\title{
CONTRIBUTIONS TO THE GEOLOGY OF URANIUM
}

\section{URANIUM IN GARBONAGEOUS ROCKS IN THE TOWNSEND AND HELENA VALLEYS MONTANA}

\author{
By George E. Becraft
}

\begin{abstract}
Uranium-bearing carbonaceous shale and lignite beds are exposed in four areas in the Townsend and Helena Valleys in western Montana. The greatest number of exposures is in an area of several square miles northeast of Winston in the Townsend Valley. The uranium-bearing beds are in the lower part of a Tertiary unit that consists largely of thin-bedded white to buff pure and impure tuffs, locally altered to bentonite.

The uranium occurrences, none of which appear to be commercial, have three characteristics in common: (1) They are in and adjacent to carbonaceous shale or lignite interbedded with light-gray or white fine-grained tuffs and lapilli tuffs; (2) the stratigraphic section in the vicinity of the deposits includes bentonite and partly bentonized tuff; and (3) the distribution of the uranium in the favorable beds is erratic. The uranium was probably leached from the tuffs and lapilli tuffs by meteoric water during bentonization and was concentrated in the carbonaceous shale and lignite.

Similar Tertiary rocks are present in many of the major valleys in western Montana and probably warrant prospecting for uranium. Areas containing white fine-grained tuff or lapilli tuff, bentonite, and coal or carbonaceous shale would be particularly favorable for prospecting.
\end{abstract}

\section{INTRODUCTION}

Uranium occurrences were discovered in Tertiary sedimentary rocks, consisting largely of volcanic debris, northeast of Winston, Mont., in the Townsend Valley early in1955. Subsequently, uranium was discovered in similar rocks near the southern end of the Townsend and eastern end of the Helena Valleys.

Both valleys are wide basins (fig. 16) in western Montana near the headwaters of the Missouri River. They are traversed lengthwise by U. S. Highway $10 \mathrm{~N}$.

Townsend is near the center of the Townsend Valley, and the Missouri River flows northward across the valley. Prickly Pear Creek 


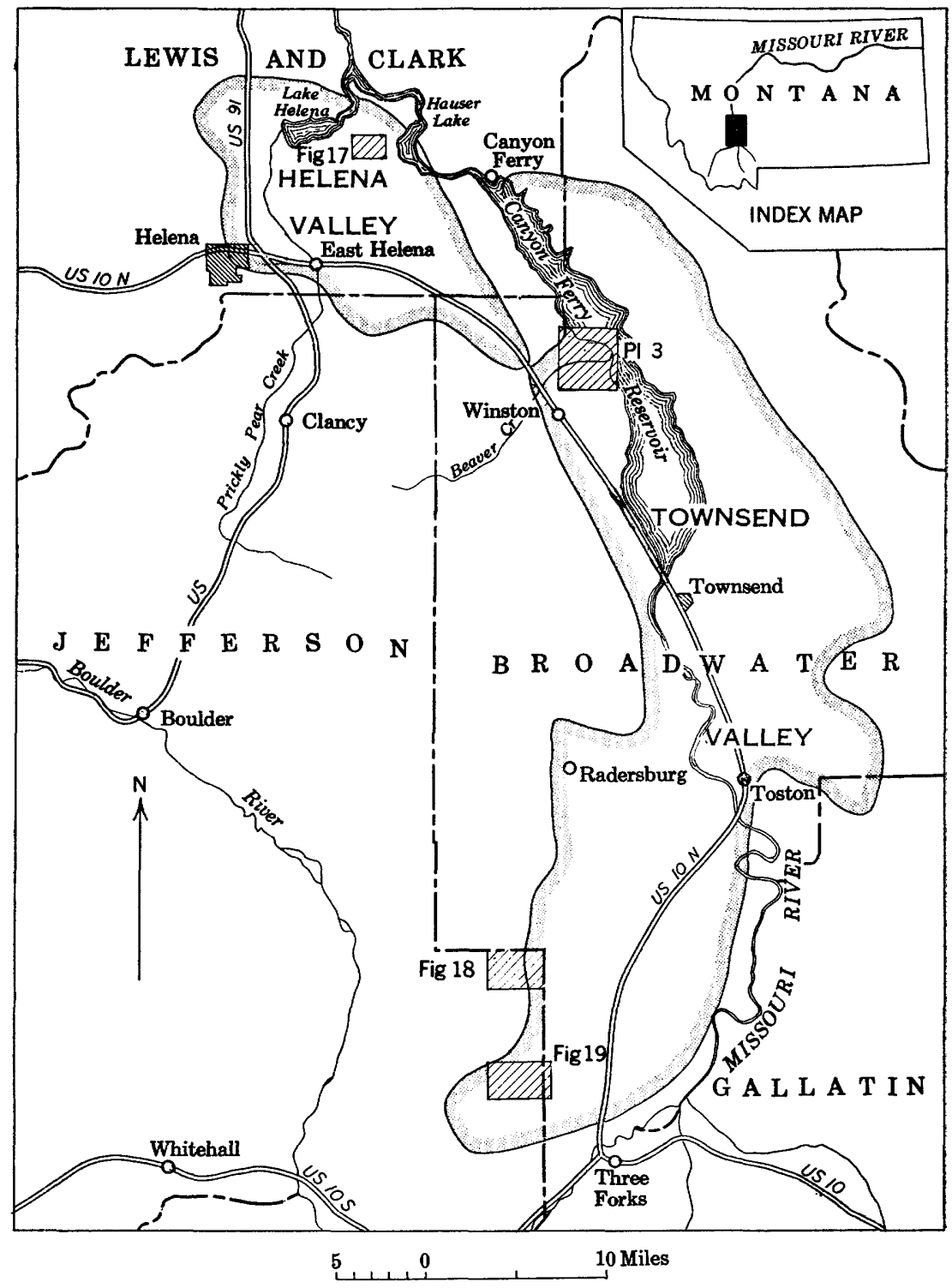

FraUn 16.-Index map showing the Townsend and Helena Valleys and the locations of plate 3 and figures 17-19.

flows northward across the Helena Valley and joins the Missouri River near the northeastern margin. Helena is near the southwestern margin of the valley.

Earlier work in the Townsend Valley includes a report on the geology and ground water by Pardee (1925); a report on the geology of the 
Canyon Ferry quadrangle, which includes the northern end of the Townsend Valley, by Mertie, Fischer, and Hobbs (1951); and a report by Freeman, Ruppel, and Klepper (1958) which includes detailed maps of most of the western part of the valley.

Brief descriptions of the geology of the Helena Valley are included in reports by Knopf (1913), Pardee and Schrader (1933), and Lorenz and Swenson (1951). Hail and Gill (1953) briefly describe slight radioactivity associated with carbonaceous shales in the valley.

During May and June 1955, the writer examined several areas containing uranium minerals and radioactivity anomalies in the Tertiary sedimentary rocks in the Townsend and Helena Valleys. Much of this time was spent making a detailed map and study of the uranium deposits northeast of Winston. Extensive radiometric surveys were made with a scintillation counter in selected areas and with a carborne scintillation counter over larger areas in both valleys. Paul E. Myers assisted the writer with much of the radiometric surveying. This examination is part of a study of the uranium deposits in and near the Boulder batholith being carried out by the U. S. Geological Survey on behalf of the Division of Raw Materials of the U. S. Atomic Energy Commission.

The writer wishes to thank the ranch owners in the vicinity of Beaver Creek for permission to cross their ranches.

\section{GENERAL GEOLOGY}

Pardee (1925, p. 1) defines the Townsend Valley as "the widened part of the valley of [the] Missouri River between Canyon Ferry and Toston and a broad lowland west of Toston . . . ." It "is about 60 miles long and 600 square miles in extent." In a brief summary of the geology of the area, he states $(1925, \mathrm{p} .2-3)$ :

The rocks consist of two groups separated by a major unconformity. The older group includes a great thickness of quartzite, shale, and limestone that range in age from Precambrian to Cretaceous and have been severely deformed and deeply eroded. Associated with these beds are intrusive and extrusive igneous rocks, chiefly of Cretaceous or early Tertiary age. These rocks compose the mountains and in the valley form the bedrock upon which the younger rocks lie.

The younger group, which occupies most of the valley, includes beds of oligocene, Miocene, Pleistocene, and Recent age.

All of the known radioactivity anomalies in the Townsend Valley are in rocks of Oligocene age. Northeast of Winston the uranium deposits are in the lower part of the Oligocene rocks, and the anomalies near the southeastern margin of the valley are in similar and probably correlative rocks.

The Helena Valley is another wide basin, separated from the Townsend Valley by a broad, low divide northwest of Winston. From 
the divide it extends northwestward about 20 miles and is about 10 miles wide at its widest part. The geology is similar to the geology of the Townsend Valley except that the Quaternary deposits are much more extensive, and as a result the Tertiary rocks in the valley are exposed only in a few small areas. A few weak radioactivity anomalies occur in rocks similar to the Oligocene rocks northeast of Winston.

\section{GEOLOGY AND URANIUM DEPOSITS OF AREAS EXAMINED IN DETAIL}

\section{AREA NORTHEAST OF WINSTON}

\section{GEOLOGY}

The area northeast of Winston (pl. 3) is near Canyon Ferry Lake in the Canyon Ferry quadrangle and extends north and south of Beaver Creek. Mertie, Fischer, and Hobbs (1951, p. 30-32) divided the Tertiary rocks in the Canyon Ferry quadrangle into 5 units. Three of these units are exposed in the area of plate 3 .

Unit 1 is poorly exposed in this area and consists of conglomerate, red shale, interbedded dark-gray, partly bentonized tuff, and bentonite. Mertie (p. 31-32) describes unit 1 as follows:

The boundaries of this unit are not well-defined. The beds include some conglomerate, which disintegrates by weathering so that the resulting material is not easy to distinguish from the terrace gravels. Along its eastern boundary, the sediments grade into those of unit 2 , so that this boundary is a matter of interpretation. The boundaries shown are therefore necessarily somewhat inexact.

The sediments of unit 1 are nowhere continuously exposed. A few outcroppings show that the unit consists of conglomerate and red shale, the latter including some bentonitic horizons, but the proportions of conglomerate to shale cannot be determined. At one site along the north side of Beaver Creek, the conglomerate is in place, and consists of well-rounded gravels, cobbles, and boulders, as much as 3 feet in diameter, with an average size of about 6 inches. They are mainly basic lava, with a small amount of quartzite. Some of the cobbles are exfoliated by weathering. The matrix consists of a yellow to reddish grit, made up of small well-rouned grains of limestone, and a small amount of other kinds of country rock. About a mile north of Beaver Creek, the red shale is exposed in an elbow-shaped bend of a small gulch. These beds are banded, tuffaceous, and bentonitic, and are composed mainly of grains as much as 0.1 millimeter in size, averaging perhaps 0.025 millimeter. The reddishbrown grains, originally glass, are altered to montmorillonite and kaolin. Angular grains of quartz, sericite, chloritized biotite, and altered iron ores are the other constituents. In the next gulch to the south, about three-fourths of a mile north of Beaver Creek, 10 feet of reddish-brown conglomerate and grit are exposed, the matrix of which is composed mainly of grains of limestone.

The author has slightly modified the contact between units 1 and 2 as mapped by Mertie, Fischer, and Hobbs $(1951, \mathrm{pl} .2)$. One modification is in the SE1/4 sec. 18 (pl. 3) where they included in unit 2 
several thick beds of conglomerate, which are made up of cobbles and pebbles of pre-Tertiary rocks, interbedded bentonite, and partly bentonized dark-gray tuffs. These rocks are typical of unit 1 and are therefore included in this unit by the author. Another modification was made near the southern margin of the Canyon Ferry quadrangle where several beds of reddish-brown conglomerate interbedded with bentonite and partly bentonized tuff are exposed along an abandoned road half a mile from Canyon Ferry Reservoir. These beds were included in unit 2 by Mertie, Fischer, and Hobbs but are included in unit 1 by the present author.

In general, the beds of unit 1 strike northwest and $\operatorname{dip} 15^{\circ}-25^{\circ} \mathrm{NE}$; however, along the abandoned road near the south margin of plate 3 , the beds strike north and dip about $40^{\circ} \mathrm{E}$. South of the road for a short distance, the beds strike northeast and dip $20^{\circ}-30^{\circ} \mathrm{SE}$. These differences in attitudes may indicate a concealed east-trending fault north of the abandoned road, an anticline plunging to the east, or a topographic high in the older rocks at the time of deposition of the Tertiary rocks. Because of lack of exposures, the reason for the differences could not be determined.

Rocks of unit 2 underlie most of the area of plate 3 and are exposed north of Beaver Creek for a distance of $23 / 4$ miles from the contact of unit 1 to Canyon Ferry Reservoir. Previous workers separated unit 2 into three parts (Mertie, Fischer, and Hobbs, 1951, p. 33-35), but in this report the lower two-thirds is considered as a single part which differs markedly from the upper one-third. The original division was based on the presence of more and thicker beds of bentonite in the lower third than in the middle third of the unit. However, the amount of bentonite present in the section differs considerably more along the strike of the unit than across the strike. Although most of the tuffs in the lower two-thirds of unit 2 are bentonized to a slight degree, the almost completely bentonized tuffs-referred to in this report as bentonites-are more common near the south margin of plate 3 and become less common northwestward along the strike of unit 2. In section 18 only a few thin beds are bentonized to the degree common south of Beaver Creek.

The lower two thirds of unit 2 is largely unaltered or only slightly altered tuff and lapilli tuff, which make up about 60 percent of the section, and bentonite, which makes up about 20 percent. The remainder of the section is tuffaceous sandstone, conglomerate, and breccia and includes many thin beds of carbonaceous shale and chert. The tuffs, lapilli tuffs, and tuffaceous sandstones are predominantly white or light gray but also include gray, cream, yellow, and buff beds. The carbonaceous shale beds range from light brown to black. 
The lithology commonly changes along strike and this makes correlation of sections very difficult.

The tuffs and lapilli tuffs consist of angular fragments of quartz, plagioclase, orthoclase, and chert and angular to subrounded fragments of pumice in a matrix of fine glassy material. The pumice fragments and matrix are largely kaolinized or bentonized. The mineral fragments make up from 10 to 50 percent of the rock.

The sandstones consist largely of subangular to subrounded grains of quartz, plagioclase, orthoclase, and chert and commonly contain rounded grains of pumice largely altered to clay. In the coarser sandstones occasional rounded grains of rhyolite are present.

The carbonaceous shales are from a few inches to 18 inches thick. Many of the shale beds contain only a small percentage of carbonaceous material, but some consist almost entirely of carbonized plant fragments.

The chert beds, which may represent tuff beds replaced by silica, are mostly less than a foot thick and are associated with bentonite or partly bentonized tuff. In places the chert is opalized.

The upper third of unit 2 differs markedly from the lower part. It consists largely of buff to gray fine-grained tuff, very little of which shows any bentonization. Beds of limestone are common, but no beds of carbonaceous shale were recognized. Mertie, Fischer, and Hobbs $(1951$, p. 35) report that two beds of diatomaceous earth occur in the upper part of the sequence.

In general, the beds of unit 2 strike northwest and dip northeast. The dip is usually greater in the lower part of the unit than in the upper part. This difference in average dip may indicate deposition in a subsiding basin. After deposition of the lower beds but before deposition of the upper beds, the basin may have subsided differentially, the greatest subsidence being east of the mapped area. In places, gentle folds superimposed on the regional structure cause local differences in the attitudes of the beds.

North of Beaver Creek, several normal faults cut the lower part of unit 2. Most faults show that the east block moved down, but some indicate a downward movement of the west block. In the southeast corner of sec. 18, the contact between unit 1 and unit 2 is offset by a normal fault that strikes about north and dips $60^{\circ} \mathrm{E}$. Most of the apparent offset, about 1,200 feet, is probably the result of erosion rather than strike-slip displacement. Banded chalcedony was deposited along some of the faults, probably by meteoric water because no evidence of hydrothermal alteration of the rocks along the faults was observed.

In sec. 7, shown in the northwest corner of plate 3, tuffs that resemble those mapped as unit 3 near Canyon Ferry (Mertie, Fischer, and 
Hobbs, 1951, p. 35-37) are in fault contact with unit 2. The tuffs are fine grained, buff colored, and massive.

The Quaternary deposits shown on plate 3 consist of gravel and sand deposits, principally on terraces cut on the tilted Tertiary rocks, and recent alluvium in the stream valleys. South of Beaver Creek the older deposits consist largely of volcanic rocks probably derived from the Elkhorn Mountains several miles west of the area. North of Beaver Creek debris from the Spokane Hills, immediately west of the area, is mixed with the gravel. These older deposits are in places at least 10 feet thick and cover very broad areas (pl. 3). Because of this gravel cover and the alluvium in the valleys, several beds of radioactive carbonaceous shale could be traced for only short distances.

\section{URANIUM DEPOSITS}

Radioactivity anomalies were detected at about 20 localities northeast of Winston (pl. 3 and fig. 16). All of the anomalies are in or adjacent to carbonaceous shales in the lower part of Tertiary unit 2. The shale beds are lenticular, and no single bed could be traced for more than a few hundred feet. Secondary uranium minerals were identified from five of the localities. No primary uranium minerals were recognized. Almost all of the carbonaceous shale in unit 2 is slightly radioactive, but only the localities where the radioactivity is several times the background radiation are shown on plate 3. Several beds of white tuff and white lapilli tuff were also slightly more radioactive than the surrounding rocks. Additional radioactivity anomalies undoubtedly exist under the extensive terrace gravel deposits but could not be detected by scintillation counter traverses because of the thickness of the gravel cover.

The radioactivity anomalies shown on plate 3 are described below.

\section{LOCALITY A}

Locality $A$ is in the $\mathrm{SE} 1 / 4$ sec. 20 near the top of the steep north slope of the broad terrace north of Beaver Creek. Uranium occurs in a poorly indurated carbonaceous shale and in a fine-grained partly bentonized gray tuff overlying the shale. Locally, lenses of sandstone in the overlying tuff also contain uranium. The shale strikes N. $15^{\circ}$ W. and dips $20^{\circ} \mathrm{NE}$. and ranges in thickness from less than 6 inches to 18 inches. The bed is exposed for a distance of about 200 feet in a bulldozed cut. The radioactivity is not of uniform intensity throughout the shale and is strongest over a strike distance of about 30 feet near the center of the exposed area. Results of drilling on the terrace indicate that the uraniferous bed extends at least a few hundred feet south of the exposed area.

A yellowish-green micaceous mineral that coats fractures in the shale and overlying tuff and replaces plant fragments in the shale 
was identified optically, spectrographically, and by X-ray diffraction pattern as metatorbernite by Jerome Stone, of the U. S. Geological Survey. The mineral fluoresces bright green. No other uranium minerals were detected at this locality.

An attempt to strip mine the uranium at this locality was made in June 1955. Because of the steep dip of the uranium-bearing bed, a considerable amount of overburden had to be removed. The overburden was stripped to the carbonaceous shale, which at this point was about 12 inches thick. Care was taken to mine only the carbonaceous shale.

\section{LOCALITY B}

Locality $\mathrm{B}$ is on the west side of a small knoll in the northeast corner of sec. 20 . The uranium is in a 12-inch-thick bed of lightreddish-brown carbonaceous shale and an underlying light-greenishgray chert bed about 6 inches thick. Overlying the carbonaceous shale is a partly bentonized lapilli tuff several feet thick. Underlying the chert bed is a 6 -foot zone of alternating chert and white tuffs. Underlying this sequence is a thick partly bentonized tuff. The beds strike N. $18^{\circ} \mathrm{W}$. and dip $22^{\circ}$. NE.

The carbonaceous shale is exposed for a strike length of about 200 feet. It pinches out toward the southeast and could not be located on the slope across a small valley to the northwest. The bed is cut off by a northeast-trending fault about 150 feet downdip from the highest exposure.

Carnotite, identified by Jerome Stone, U. S. Geological Survey, coats fractures and has partly replaced plant fragments in the carbonaceous shale. In several places carnotite also coats fractures in the underlying chert. A selected sample of the carbonaceous shale assayed 0.28 percent of $\mathrm{eU}, 0.70$ percent of $\mathrm{U}$, and 0.2 percent of $\mathrm{V}^{1}$. A selected sample of carnotite-coated chert assayed 0.019 percent of eU, 0.022 percent of $U$, and 0.01 percent of $V$. A bulk sample from a small ore pile assayed 0.062 percent of $\mathrm{eU}$. The bulk sample was ground and separated into size fractions and each fraction was then assayed for equivalent uranium, with the following results:

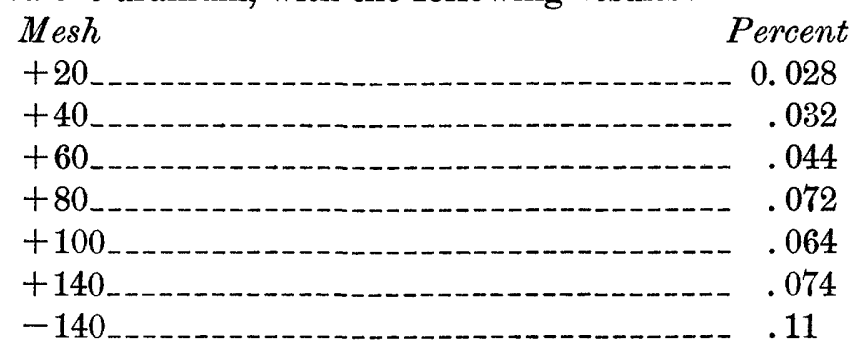

${ }^{1}$ All vanadium analyses in this report were made by $\mathbf{K}$. E. Valentine, U. S. Geological Survey. 
By weight, one-half of the sample is finer than 60 mesh. These data indicate that the bulk of the uranium is in the finer fractions and the uranium might be concentrated by grinding and screening.

\section{LOCALITY C}

Locality $\mathrm{C}$ is on a low rounded spur near the bottom of a broad valley in sec. 18. The uranium is in a brown carbonaceous shale bed about 8 inches thick. This shale is overlain by a thin soil cover and underlain by a 4 -inch bed of white, fine-grained tuff which is underlain by another 8-inch carbonaceous shale bed. These carbonaceous shale beds are more indurated than those at localities $\mathrm{A}$ and $\mathrm{B}$.

The beds are exposed for a total distance of about 50 feet in two shallow bulldozer cuts; elsewhere they are covered by colluvium. The attitude of the beds is $\mathrm{N} .80^{\circ} \mathrm{W} ., 7^{\circ} \mathrm{NE}$. Only the upper shale bed is strongly radioactive. A selected sample of the upper shale assayed 0.051 percent of eU, 0.10 percent of $U$, and 0.03 percent of $V$. No uranium minerals were detected.

\section{LOCALITY D}

Locality $\mathrm{D}$ is an outcrop at the northwest end of a low mound near the center of a broad valley in sec. 18 (pl. 3). The uranium is in black well-indurated carbonaceous shale about 6 inches thick overlying a 12-inch dark-gray chert bed and underlying a lighter gray chert bed at least 8 inches thick. The beds strike about N. $40^{\circ} \mathrm{W}$., dip about $3^{\circ} \mathrm{NE}$., and are exposed for a distance of about 30 feet. Carnotite occurs in the black shale and coats fractures in the underlying chert. A selected sample of the black shale assayed 0.11 percent of eU, 0.20 percent of $\mathrm{U}$, and 0.3 percent of $\mathrm{V}$.

About 500 feet southeast of this outcrop, a radioactive greenishgray partly bentonized lapilli tuff bed about 4 feet thick is exposed in a bulldozer cut. The bed is overlain and underlain by gray, partly bentonized tuff. The bed is exposed for a distance of about 100 feet and has an attitude of N. $20^{\circ} \mathrm{W} ., 25^{\circ} \mathrm{NE}$. The radioactive material is distributed erratically in the bed. A selected sample of the radioactive material assayed 0.069 percent of $\mathrm{eU}$.

\section{LOCALITY E}

Locality $E$ is in a shallow bulldozer cut on the north side of a small ridge near the center of the western margin of sec. 20 . The uranium is in a carbonaceous shale exposed over an area of only a few square feet near the bottom of the south wall of the bullozer cut. The rock surrounding the carbonaceous material is partly bentonized tuff and bentonite. In the vicinity of the anomaly, the rocks are cut by several small, highly irregular faults and about 40 feet east of the anomaly 
by a larger fault. The details of the structure are difficult to determine because of poor exposures and bentonite flowage. No uranium minerals were recognized, but a selected sample of the highly carbonaceous material assayed 0.12 percent of $\mathrm{eU}, 0.23$ percent of $\dot{U}$, and 0.02 percent of V. A composite sample of the bentonite in the vicinity contained 0.002 percent $\mathrm{eU}$ but no uranium.

\section{LOCALITY F}

Locality $F$ is about 250 feet north of locality $E$ in sec. 20 . A sequence about 6 feet thick of carbonaceous beds and fine-grained tuff beds is exposed in a road cut. The carbonaceous beds range from lignite to shales containing only a small amount of plant fragments. The beds are from 2 to 12 inches thick and strike N. $15^{\circ} \mathrm{W}$. and $\operatorname{dip} 25^{\circ} \mathrm{NE}$. The sequence is overlain by bentonite and underlain by partly bentonized tuff. A bentonitic mudflow covers the beds to the west of the road cut, and the beds are cut off near the east end of the cut by a fault which strikes N. $10^{\circ} \mathrm{W}$. and dips $62^{\circ} \mathrm{SW}$. East of the fault the rock is white sandy tuff made up of 30 to 50 percent of rounded pumice fragments and about 10 percent of rounded grains of chert in a fine-grained glassy matrix.

Several of the carbonaecous beds are radioactive. A sample from a 2 -inch bed of lignite about 12 inches above the base of the sequence assayed 0.015 percent of $\mathrm{eU}$ and 0.022 percent of $\mathrm{U}$. A sample selected from the most radioactive bed in the sequence-a 6 -inch bed of reddish-brown carbonaceous shale about 4 feet above the base-assayed 0.051 percent of $\mathrm{eU}$ and 0.021 percent of $\mathrm{U}$. A bulk sample of all the carbonaceous beds assayed 0.008 percent of eU and 0.009 percent of $\mathrm{U}$.

\section{LOCALITY G}

Locality $G$ is a large area south of Beaver Creek in sec. 28. The rock in this area is predominantly bentonite with smaller amounts of partly bentonized tuffs and lapilli tuffs. Three beds of carbonaceous shale in the area of bentonite are radioactive. The lowest shale bed in the section is 3 inches thick and is underlain by a 6 -inch chert layer which is underlain by bentonite. The bentonite appears to have been a lapilli tuff consisting largely of ash and rounded fragments of pumice about a quarter of an inch in diameter. Overlying the shale is a sandy tuff, about 2 feet thick, that consists almost entirely of rounded pumice fragments altered to bentonite, in a matrix of glassy material largely altered to clay. About 50 feet higher in the section is a 4 -inch bed of carbonaceous shale and about 2 feet higher is another carbonaceous shale bed about 2 inches thick. The beds between the shales are almost completely altered to bentonite. These beds strike 
N. $30^{\circ}-35^{\circ} \mathrm{W}$. and dip $25^{\circ}-40^{\circ} \mathrm{NE}$. The carbonaceous beds are exposed for a distance of about 250 feet. Metatorbernite is found locally along fractures in the lowest shale bed, and samples selected from two of the beds assayed 0.36 and 0.054 percent of eU. Nonradioactive, thoroughly silicified plant fragments and logs are associated with the bentonite at several places.

\section{LOCALITIES H-U}

Localities $\mathrm{H}-\mathrm{U}$ shown on figure 2 are similar to those described above, but the uranium content is generally considerably lower; for comparison, information on all of the localities is presented in the following table.

Percent of equivalent uranium and uranium in samples from localities shown on plate 3

\begin{tabular}{|c|c|c|c|c|}
\hline Locality & $\theta U$ & $\mathbf{U}$ & Kind of sample & $\begin{array}{l}\text { Thickness } \\
\text { of bed } \\
\text { (inches) }\end{array}$ \\
\hline$-\ldots$ & 10.28 & 0.70 & Carbonaceous shale containing carnotite $\ldots . .$. & 12 \\
\hline (n) & 1.019 & .022 & Chert with carnotite coated fractures. & 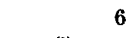 \\
\hline - n & .062 & $\left({ }^{2}\right)$ & Carbonaceous shale and chert. & (3) \\
\hline n............ & 1.051 & .10 & Carbonaceous shale & 8 \\
\hline $\mathrm{C}$ & .23 & $(2)$ & Carbonaceous shale & \\
\hline C................. & .24 & $(2)$ & Carbonaceous shale & - \\
\hline - & 1.11 & .20 & Carbonaceous shale containing carnotite & 6 \\
\hline$\ldots . . .$. & .069 & (2) & Partly bentonized lapilli tuffi & 12 \\
\hline (n) & .034 & (2) & Carbonaceous shale containing carnotite.............. & 6 \\
\hline 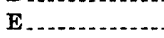 & 1.12 & .23 & Carbonaceous shale & \\
\hline ............. & .20 & $(2)$ & Carbonaceous shale & \\
\hline E. & 4.002 & 0 & Bentonite & (3) \\
\hline F. & 4.015 & .022 & Carbonaceous shale . . ..... & 2 \\
\hline $\mathbf{F}$. & 4.051 & .021 & Carbonaceous shale........... & 6 \\
\hline $\mathbf{F}$. & 4.008 & .009 & Carbonaceous shale. & (3) \\
\hline G. & .36 & $\left({ }^{2}\right)$ & Carbonaceous shale containing metatorbenite. & 3 \\
\hline G.. & .054 & $(2)$ & Carbonaceous shale. & 4 \\
\hline H............ & 4.007 & .004 & Partly bentonized fine-grained tuff & 12 \\
\hline $\mathbf{H}$ & 4.013 & .009 & Fine-grained tuff & ... \\
\hline $\mathbf{J}_{\ldots} \ldots \ldots \ldots \ldots$ & 4.004 & 0 & Tuffaceous sandstone & 36 \\
\hline $\mathbf{K}$. & 4.004 & & Coarse, partly bentonized sandstone & \\
\hline L.... & 4.013 & .019 & Silicified wood & (5) \\
\hline M. & 4.038 & .071 & Brown carbonaceous shale & 7 \\
\hline N.. & 4.005 & .003 & White coarse sandy tuff & 48 \\
\hline P. & 4.008 & .006 & Gray tuff with plant fragments & 48 \\
\hline & 4.009 & .004 & Tuffaceous sandstone & 24 \\
\hline & 4. 018 & .036 & Carbonaceous shale containing carnotite & 18 \\
\hline Q........... & 4.001 & 0 & Light-gray chert & 12 \\
\hline $\mathbf{R}$ & 4.007 & .005 & Carbonaceous shale & 8 \\
\hline & 4.011 & .012 & Carbonaceous shale.. & 6 \\
\hline & .009 & $(2)$ & Brown chert.............. & 4 \\
\hline U... & .010 & $(2)$ & Carbonaceous shale & 6 \\
\hline
\end{tabular}

1 Analysts: Benjamin A. McCall and Roosevelt Moore.

2 Not determined.

3 Bulk sample.

4 Analysts: C. Angelo and M. Finch.

$\checkmark$ Fossil tree trunk fragment. 


\section{AREA WEST OF HAUSER LAKE}

The area shown on figure 17 is on the drainage divide between Hauser Lake and Lake Helena in the Helena Valley (fig. 16). Most of the area is covered by Quaternary gravel and soil, much of which is cultivated. Tertiary rocks are exposed in three small areas (fig. 17). The westernmost exposure of Tertiary rocks in sec. 29 consists
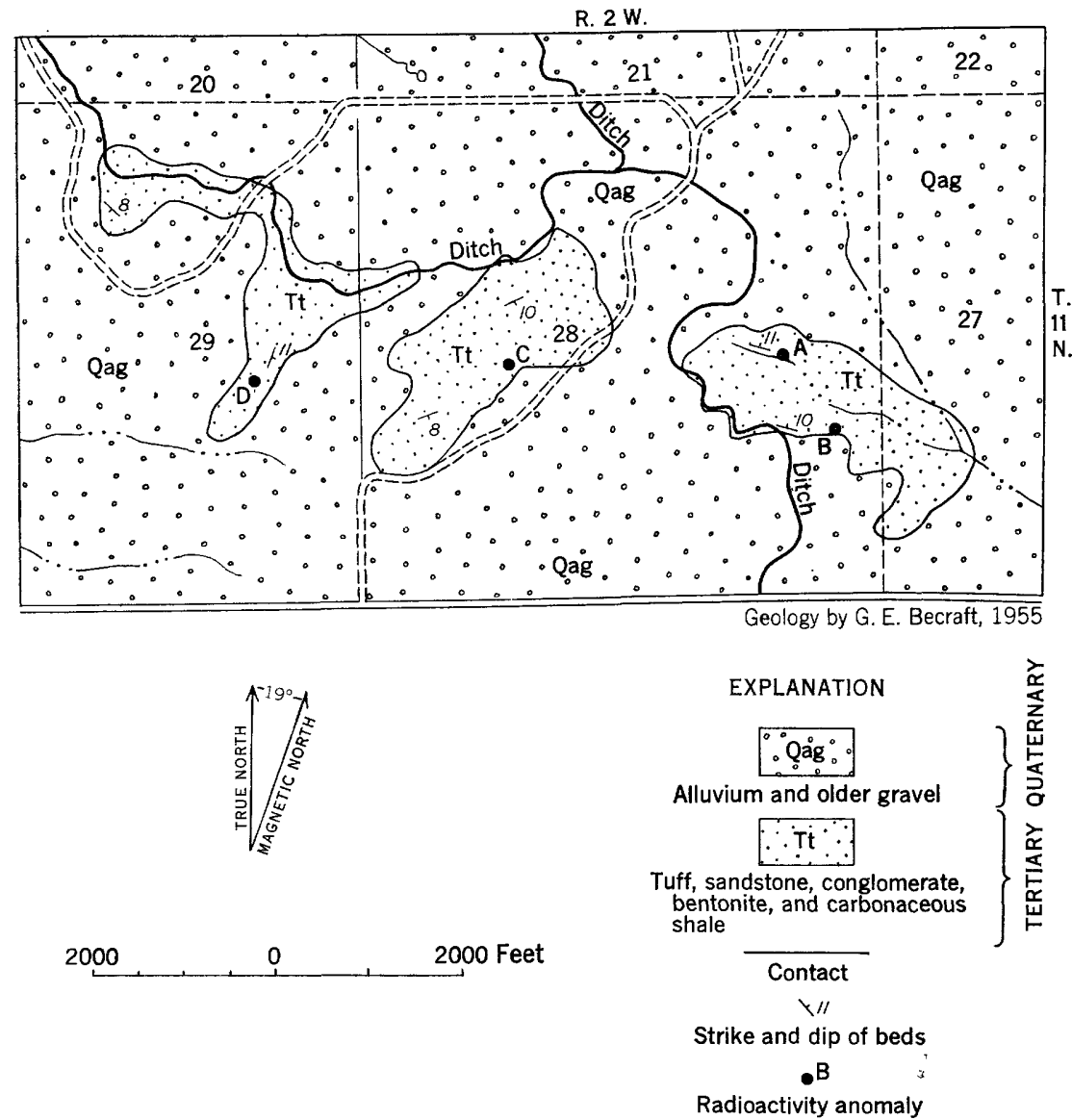

FIgure 17.-Geologic map showing radioactivity anomalies west of Hauser Lake in the Helena Valley, Mont.

of conglomerate, tuffaceous conglomerate, tuffaceous sandstone, and bentonite. The conglomerate consists of pebbles and cobbles of dark volcanic rock, quartzite, and limestone, but is not well indurated and tends to crop out only as layers of loose gravel. Most of the conglomerate beds are broadly lenticular and crossbedded; together with the tuffaceous conglomerate they make up about one-half of the nonbentonitic rocks in the section. The tuffaceous conglomerate beds 
consist of varying amounts of pebbles, similar to those in the conglomerate, which are embedded in a matrix of tuff now largely altered to clay. The remainder of the nonbentonitic rocks in the section are gray, partly bentonized tuffs and light-gray tuffaceous sandstone, which consists of rounded grains of chert and fragments of pumice in a glassy matrix now largely altered to clay. The bentonite is in beds from 4 to 12 feet thick and it appears to have been formed from alteration of fine-grained tuff. It is largely gray but contains a few beds that are purplish-brown because of carbonaceous material in the beds. The attitude of the beds in this vicinity is $\mathrm{N} 45^{\circ} \mathrm{W} ., 8^{\circ} \mathrm{SW}$.

In the vicinity of locality $D$, the section contains less nonvolcanic material than it does farther north. About 20 percent of the section is conglomerate or sandy conglomerate, about 30 percent is bentonite, and the remainder is largely partly bentonized tuff and lapilli tuff. The rocks are well bedded, and most beds are less than 1 foot thick. Four beds of purplish-brown carbonaceous shale ranging in thickness from 1 to 4 inches, are interbedded with light-gray partly bentonized tuff near the top of the exposed section. All of the carbonaceous shale is slightly radoactive. A selected sample from the lowest bed assayed 0.011 percent of $\mathrm{eU}$.

In the vicinity of locality $C$, the rocks are predominantly light-gray sandstone and greenish-gray bentonite. Some beds contain many rounded pebbles of older rocks, and a few broadly lenticular beds of conglomerate are interbedded with both the bentonite and the sandstone. Most of the sandstones and conglomerates are crossbedded. A 1-inch bed of purplish carbonaceous shale at locality $C$ is slightly radioactive, but it is not so radioactive as the shale at locality $D$.

The Tertiary rocks in the vicinity of localities $A$ and $B$ are partly bentonized fine-grained tuff and bentonite. Interbedded with these are a few beds of light-gray, partly bentonized lapilli tuff. The lapilli are subrounded fragments of light-gray fine-grained tuff about one-fourth inch in diameter.

At locality $B$ are four slightly radioactive beds of light purplishgray thin-bedded carbonaceous shale from 3 inches to 1 foot thick, and two thin, slightly radioactive beds of carbonaceous shale crop out at locality $A$. The shale at localities $A$ and $B$ is less radioactive than the shale at locality $C$.

\section{AREA IN T. 3 N., R. 1 W.}

The area shown in figure 18 is near the south end of the Townsend Valley (fig. 16). Most of the area is under cultivation and outcrops are poor. At locality $A$ (fig. 18), a 4-foot bed of white lapilli tuff 


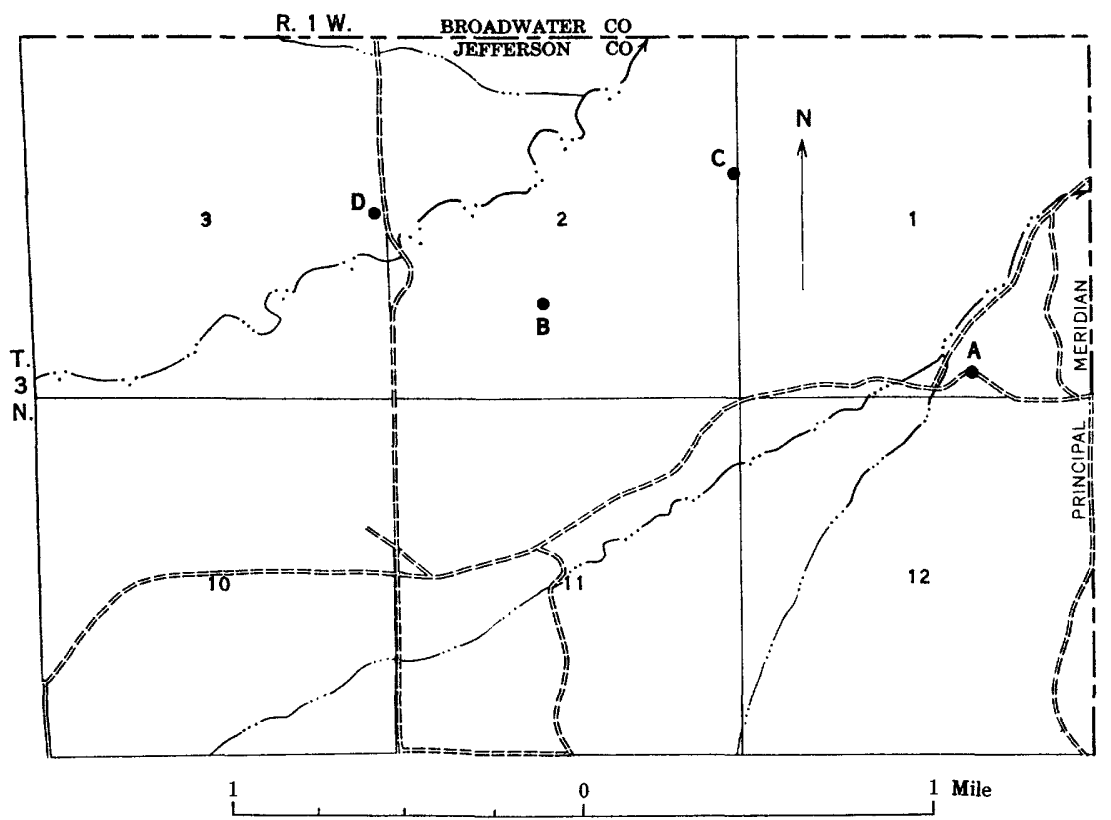

FIGCRE 18.-Radioactivity anomalies in T. 3 N., R. 1 W. near the southern end of the Townsend Valley, Mont.

exposed on the southwest side of a small valley consists of large rounded pumice lapilli in a fine-grained matrix. It is crossbedded and overlies bentonite. A sample taken across 3 feet of tuff assayed 0.004 percent of $\mathrm{eU}$ and 0.002 percent of $\mathrm{U}$. A similar slightly radioactive white lapilli tuff is exposed along a low bluff at locality $C$.

At locality $B$, a 5 -inch bed of light-purplish-gray carbonaceous shale is interbedded with gray, partly bentonized tuff and locally is partly replaced by chert. A selected sample of the carbonaceous shale assayed 0.006 percent of $\mathrm{eU}$ and 0.018 percent of $\mathrm{U}$. At locality $D$ a radioactivity anomaly was detected with a car-borne scintillation counter near the base of a small knoll, but the source of radioactivity was not found. Outcrops are poor, but float indicates that the knoll is capped by a bed of white lapilli tuff similar to that at locality $A$.

AREA IN T. 2 N., R. 1 W.

The area shown in figure 19 is about 5 miles south of the area of figure 18 at the southern end of the Townsend Valley (fig. 16). Almost all of the area is under cultivation, and outcrops are extremely poor. The large amount of bentonite in the soil and on the graded roads and the few outcrops of tuffaceous rocks indicate that the area is probably entirely underlain by Tertiary rocks similar to those northeast of Winston. 


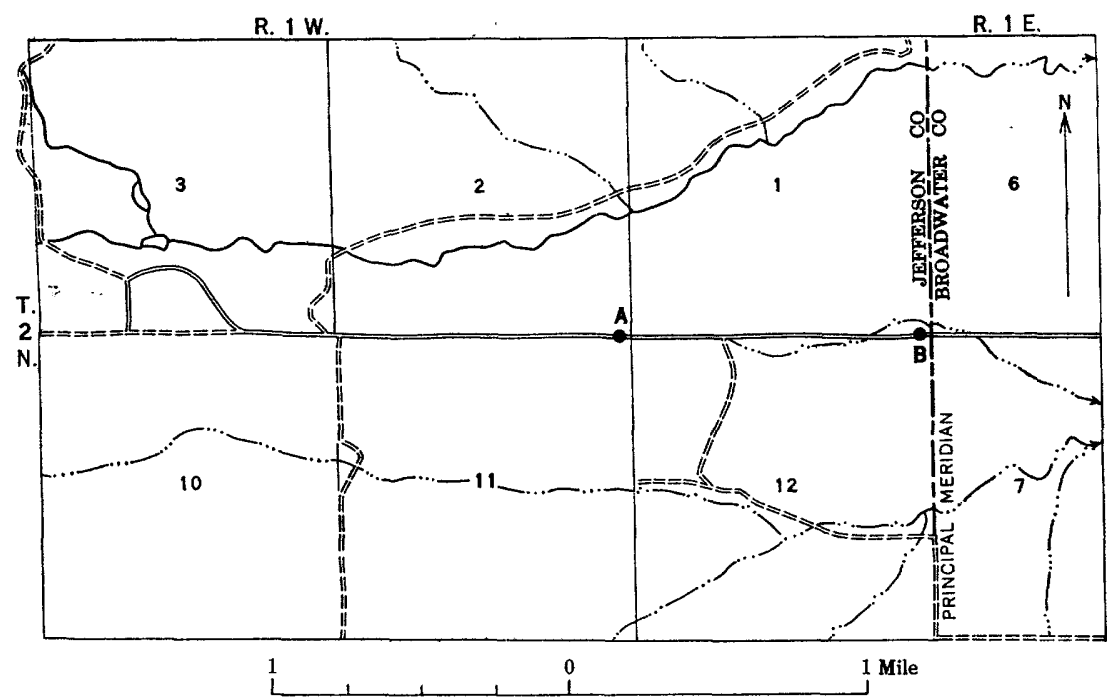

FIGURE 19.-Radioactivity anomalies in T. 2 N., R. 1 W., near the southern end of the Townsend Valley. Montana.

At locality $A$ (fig. 19) a slightly radioactive bed of reddish-brown carbonaceous shale 10 inches thick is exposed on both sides of a graded country road. The carbonaceous shale is interbedded with partly bentonized fine-grained tuff, sandstone, and bentonite. About 6 feet above the shale is a thin bed of limestone.

At locality $B$ a slight radioactivity anomaly was detected with a car-borne scintillation counter. The source of the radioactivity could not be located definitely, but it might be the small amount of carbonaceous shale in the soil.

\section{ORIGIN OF THE URANIUM DEPOSITS}

In the Townsend and Helena Valleys, the uranium deposits have several characteristic features in common: they are in and adjacent to carbonaceous shale or lignite interbedded with light-gray or white fine-grained tuffs and lapilli tuffs; the stratigraphic section in the vicinity of the deposits includes bentonite and partly bentonized tuff; the distribution of the uranium in the favorable beds is erratic. The source of the uranium was probably the light-gray and white finegrained tuffs and lapilli tuffs, samples of which contain 0.002 to 0.009 percent of uranium. A bulk sample of the bentonite, which was formed by alteration largely from similar tuffs and lapilli tuffs, contained no uranium, and no radioactivity was detected in the bentonite during radiometric traversing. These data suggest an epigenetic origin for most of the uranium in the carbonaceous shale and lignite. The uranium was probably leached from the tuffs and 
lapilli tuffs by meteoric water during bentonization and was concentrated in the carbonaceous shale and lignite, essentially in the manner suggested by Denson (1952) for other deposits of uranium in coal, lignite, and carbonaceous shale in the Rocky Mountain region.

Faulting is common in the Tertiary rocks. Northeast of Winston the development of banded chalcedony along some faults indicates that the meteoric $r$ :ter that had leached silica from the surrounding rocks moved along the fault. However, no direct relation of the uranium deposits to faults was found, nor was any other structural control apparent.

\section{SUGGESTIONS FOR PROSPECTING}

Tertiary rocks similar to the rocks described in this report are widespread in many of the major valleys in western Montana. W. J. Hail, Jr., and J. R. Gill (1953) examined many of the known occurrences of coal, lignite, and carbonaceous shale in these valleys, but large areas of Tertiary rocks are still unexplored. Areas of fine-grained white tuff or lapilli tuff, areas of bentonite, and areas containing coal, lignite, or carbonaceous shale warrant detailed prospecting with a scintillation counter. Areas of white rocks or of bentonite can be detected easily on aerial photographs or from the air; thus, actual prospecting should be preceded by aerial reconnaissance and a careful study of aerial photographs. Then traverses using car-borne scintillation counters could be planned for the most promising areas, and traverses on foot could be made where necessary.

\section{LITERATURE CITED}

Denson, N. M., and others, 1952, Summary of uranium-bearing coal, lignite, and carbonaceous shale investigations in the Rocky Mountain region during 1951 : U. S. Geol. Survey TEI-341A, 44 p., issued by U. S. Atomic Energy Comm. Tech. Inf. Service, Oak Ridge.

Freeman, V. L., RuppeI, E. T., and Klepper, M. R. 1958, Geology of part of the Townsend Valley, Broadwater and Jefferson Counties, Mont.: U. S. GeoI. Survey Bull. 1042-(in press).

Hail, W. J., Jr., and Gill, J. R., 1953, Results of reconnaissance for uraniferous coal, lignite, and carbonaceous shale in western MIontana: U. S. Geol. Survey Circ. 251, 9 p.

Knopf, Adolph, 1913, Ore deposits of the Helena mining region, Montana: U. S. Geol. Survey Bull. 527, 143 p.

Lorenz, H. W., and Swenson, F. A., 1951, Geology and ground-water resources of the Helena Valley, Mont.: U. S. Geol. Survey Circ. 83, 68 p.

Mertie, J. B., Jr., Fischer, R. P., and Hobbs, S. W., 1951, Geology of the Canyon Ferry quadrangle, Montana: U. S. Geol. Survey Bull. 972, 97 p.

Pardee, J. T., 1925, Geology and ground-water resources of Townsend Valley, Mont.: U. S. Geol. Survey Water Supply Paper 539, 61 p.

Pardee, J. T., and Schrader, F. C., 1933, Metalliferous deposits of the greater Helena mining region, Montana: C. S. Geol. Survey Bull. 842, 318 p. 